\title{
STANDARDIZATION OF INTERNAL SHARIA AUDIT
}

\section{Irina V. Novikova ${ }^{1}$}

Firdaus I. Kharisova ${ }^{2}$

\begin{abstract}
The significant growth rates of the Islamic economy and the great interest in Islamic financial products and services from among other non-Islamic partners have determined the need to tighten control over the observance of Sharia norms and rules by Islamic Financial Institutions. Internal audit has long established itself as one of the most effective means of internal control and improving the efficiency of
\end{abstract} organizations. That is why AAOIFI has developed a new standard, "Internal Sharia Audit," which should form the basis for the operation of the largest IFIs in Malaysia and the Gulf countries. For Russia, this standard is of particular interest in the changing context of financial markets and the redistribution of investment flows. The paper provides a brief overview of the most significant provisions of the presented standard. Details were considered regarding significant changes from the earlier standard released by AAOIFI. Based on the fundamental principles of audit activity, special attention is paid to the organizational independence and objectivity of internal Sharia auditors, as well as to quality control of the audit procedures. As in the standard itself, the paper analyses the requirements for the skill level of internal Sharia auditors.

Keywords: internal Sharia audit, Islamic financial institutions, AAOIFI standards, Islamic banking, internal audit standards.

\section{Introduction}

Today, Islamic banking is a specific segment of the financial industry, which has a number of features, such as the prohibition of loan interest, as well as transactions with excessive uncertainty, investment in the production and sale of pork and alcohol, gambling, etc. It is based on operations with real assets, and not with money as such. This topic has been actively discussed by

\footnotetext{
${ }^{1}$ Kazan Federal University. Email: irina_8807@bk.ru.

${ }^{2}$ Kazan Federal University.
} 
Russian scientists and politicians, but the number of transactions made on the principles of Islamic finance is not large. Islamic financial institutions (IFIs) are mainly concentrated in the Middle East, the Persian Gulf, Malaysia and Indonesia. Their total assets for 2016 were estimated at $\$ 2$ trillion, and the dynamics of their increase for 2009-2013 amounted to $15 \%$, and according to forecasts, by 2025 , the assets of the Islamic economy could reach $\$ 7$ trillion.

Thus, even with the projected global decline in the growth rates of Islamic banks' assets to 5\%, such large financial flows can become an alternative to Western financing, limited by sanctions. At the same time, it is necessary not only to create an appropriate regulatory framework for the work of international Islamic financial institutions but also to introduce an Islamic model of financing in the domestic financial services market.

In Russia, Islamic banking is still in its infancy and, according to some estimates, now amounts to only 1.5 billion roubles. The KPMG calculated that about $12 \%$ of Russian Muslims (7-8 million people) are ready to use Islamic banking and its potential banking capacity reaches $500-700$ billion roubles taking into account export and import operations, supplies of halal food from Russia, infrastructure projects, coinvestment of the largest sovereign funds of the Persian Gulf countries (Banking according to the canons of Sharia, 2018).

The great stability of the Islamic financial system is dictated, first of all, by the fact that Islamic finance is a specialized area, which is based on the Koran and the Sunna. A clear understanding of acceptable financial transactions, the global objectives of the IFI and how to achieve them is assumed here. The basis of corporate governance, in this case, is the concept of equality, justice, moral principles and social responsibility. The situation is complicated by the fact that in the Islamic financial environment there is still no strictly normative regulation of the IFI. The initiator in this direction was the Accounting and Auditing Organization of Islamic Financial Institutions (hereinafter - AAOIFI). AAOIFI is an organization founded in 1991 and has a head office in Bahrain; it is a leading international non-profit organization which is primarily responsible for the development and 
implementation of standards of the global Islamic finance industry. Currently, it has already issued a total of 100 standards in the field of Sharia, accounting, auditing, ethics, and the management of international Islamic finance. The activities of this organization are supported by government agencies in more than 45 countries, including central banks and other regulatory bodies, financial institutions, accounting, auditing, and law firms. The standards developed by the organization are currently used by all leading Islamic financial institutions and form the basis for harmonizing the international practice of Islamic finance (Official website of Bloomberg news agency).

\section{Methods}

When writing the paper, methods of analysis and synthesis of information were used, as well as a method of generalization and comparison.

\section{Results And Discussion}

Recently, a draft of the new standard "Internal Sharia Audit" has been submitted for discussion by reputable AAOIFI experts. This standard is of particular interest in light of the fact that the scope of the internal Sharia audit is much wider than the internal audit conducted according to traditional rules. Here it is necessary to evaluate in detail the various socio-economic aspects of doing business.

An audit should not only be a legal or technical assessment of business operations but should have a more balanced, integrated and holistic approach, including technological, ethical and Maqasid-based audit procedures (Zakaria et al., 2019; Kharisova et al., 2018; Ryabchenko, 2018).

Let us consider in more detail the main provisions contained in this document.

"The purpose of this standard is to build on the basis of an earlier standard and provide improved guidance on internal Sharia auditing (ISA) in international financial organizations that conduct their activities in accordance with the principles and rules of Sharia. The standard prescribes compliance with the law, quality control and ethical requirements, goals and organizational structure, as well as professional 
requirements regarding the basic procedures, documentation and reporting for internal audit for compliance with Sharia.

This revised standard, in particular, introduced the following significant changes from the earlier standard:

a. the scope and structure of the internal audit for compliance with Sharia are developed, and the functions of internal audit for compliance with Sharia are clearly defined;

b. clearer definitions related to the internal audit for compliance with Sharia have been added;

c. set out the detailed objectives of the internal audit for compliance with Sharia;

d. the differences between the internal audit on compliance with Sharia and the function of compliance with the Sharia are clarified;

e. clarifies the overall responsibility and key aspects of creating an internal audit for compliance with Sharia;

f. the possibility of outsourcing internal audit to Sharia compliance is specifically allowed to meet the needs of
361

certain international financial organizations;

g. a detailed description of the organizational reporting of the internal audit on compliance with the Sharia is provided;

h. Integration of internal audit for compliance with Sharia with employees (human resources) was developed;

i. includes guidance on the use of technology in internal audit for compliance with Sharia;

j. for better understanding, the standard added the basic procedures and processes of internal audit for compliance with Sharia;

k. minimum documentation and archiving requirements are included;

1. included guidance on the contents of the types of an internal audit report for compliance with Sharia" (Official site AAOIFI).

As can be seen from the presented paragraphs of the standard, AAOIFI took into account during its development both the general tendency to expand the scope of Islamic finance, and, in particular, global trends in the development of the economy and internal audit. It is important that the 
standard defines the basic concepts related to the internal audit on compliance with Sharia, as this helps to standardize the activities of the IFI, and the significant growth rate of Islamic finance is increasingly attracting to this area people who profess the Muslim faith. It is in this case that detailed wording of the basic concepts and a detailed description of the procedures performed, taking into account the specifics of the activity, can significantly improve the work of internal auditors for compliance with the Sharia and the activity of Islamic financial institutions (IFIs) in general.

The proposed standard provides the following hierarchy of Sharia principles and rules:

"1. Sharia standards issued by AAOIFI;

2. Regulations issued by the regulatory body of the relevant jurisdiction, since they entail regulatory requirements of Sharia;

3. Decisions of the central Sharia council of the relevant jurisdiction (if one exists);

4. The requirements of the applicable financial reporting standards issued by AAOIFI, if they are related to the requirements of Sharia;

5. Recommendations and decisions are given by the Sharia Supervisory Board of the IFI. " (Official site AAOIFI).

Thus, the principles and rules described in the published AAOIFI standards are prevailing, and so the laws of those states where Sharia principles are described at the legislative level. For Russia and other countries that do not have such a regulatory framework, the creation of Sharia councils of various jurisdictions is necessary, as well as the maximum reduction of financial legislation to a state that does not contradict these standards.

Particular attention in the standard is paid to the independence and objectivity of internal auditors for compliance with the Sharia, as well as to the quality control of on-going procedures. This problem is not accidental, and it has long been analysed in countries with a predominantly Islamic economy. Thus, in the studies of Malaysian scientists, it is indicated that "internal audit for compliance with Sharia will be independent of management and core activities only 
when it would subordinate to functions of a higher level, that is, the Audit Committee, the Board of Directors or the Sharia Committee. It is argued that the strength of the internal audit for compliance with Sharia should be assessed in terms of the level of independence from the core business that it uses. It is also assumed that proper independence can be achieved by reporting at levels within the organization that allow the internal audit for compliance with Sharia to fulfil their duties without interference, having direct contact with the management and senior management, as well as having unlimited access to documents, employees and departments (Zakaria et al., 2019; Arwani, 2018; Khalid et al., 2018).

Given the IFI specifics, the internal auditors have a special responsibility to comply with Sharia. They should be very careful in their conclusions and should always be critical of any controversial situations, based primarily on the positions of the Koran and the Sunnah. In world practice, there have already been cases when some financial instruments actively used by banks in Malaysia were not recommended at first and then completely banned by the AAOIFI Sharia Council. That is why the independence and objectivity of internal auditors for compliance with Sharia are of particular importance in those countries where there is no appropriate regulatory framework and the level of training of specialists in the field of Islamic finance does not always meet the high requirements stated by AAOIFI. So, according to the standard: "The organizational status of the internal audit function in accordance with Sharia must correspond to its responsibilities with independence and objectivity. The function of internal audit for compliance with Sharia should be independent of management, but not necessarily independent of the organization (IFI).

Management should ensure that the function of internal audit for Sharia compliance has unrestricted access to all documents, reports, systems, etc. Management, the audit committee and the Sharia Supervisory Board should provide full and on-going support for the function of internal audit for compliance with Sharia. The function of internal audit for compliance with Sharia should have direct and regular contacts with all 
levels of management, SSB and external auditors for compliance with Sharia.

Internal auditors for Sharia compliance should not carry out any IFI operational activities or perform any management functions, including product development and Sharia compliance.

The function of internal audit on compliance with Sharia should have a mechanism for assessing quality and improvement. It is important that this mechanism includes an independent evaluation by independent team members (either at a higher level or at a peer level). As a rule, this includes regular supervision and quality control checks to identify and correct any defects in the process, as well as to ensure that the function of internal audit for compliance with Sharia effectively fulfils its responsibilities.

The function of internal audit for compliance with Sharia should have clear, documented principles regarding the scope of independent review and responsibilities. As a general guide, it should cover the following:

a. frequency of independent evaluations;

b. scope of assessments; c. the qualifications and level of training of those responsible for conducting the assessment. "(Official site AAOIFI).

Of particular importance in conducting an internal audit on compliance with Sharia is the human resource, therefore, considerable attention in the standard is paid to the professional competence of employees conducting internal audits for compliance with Sharia.

Based on the Islamic worldview, an individual's competence is the ability to ensure the availability of human capital in the form of human talent management to produce a sufficient number of competent employees and experts for Sharia compliance, which are crucial for promoting innovation in the field of Islamic financial products and services (Ali et al., 2018).

That is why AAOIFI establishes in its standard a significant amount of requirements for internal Sharia auditors and emphasizes the need for continuous development and self-education. So, according to the standard:

"The IFIs (in addition to those specified in the AAOIFI standard) 
should also develop their own criteria for the staff assigned to carry out the internal audit for compliance with Sharia, which should be an interdisciplinary team and should consist of experts in the field of Sharia, audit, internal control and regulatory compliance. The staff should also be well aware of the general principles, products, and processes of Islamic finance.

The function of internal audit for compliance with Sharia should support technical competence through continuing education and training, mainly in the areas of audit and knowledge for compliance with Sharia, with an emphasis on Fiqh al-Muamalat.

The head of the internal audit on compliance with Sharia is responsible for continuing the training of its employees in order to maintain their qualifications and inform about improvements and current events in coordination with the human resources department of this institution."

The standard has special requirements to the head of internal audit for compliance with Sharia, which are separately described in Appendix B:

"a. have a higher education or professional qualification (preferably in
365

the field of accounting, auditing, internal audit and / or audit for compliance with Sharia) suitable for this position;

b. be sound in the operations and functions of Islamic banking and / or finance, the relevant Sharia principles and rules, including, in particular, those contained in the hierarchy of this standard, and also have an understanding of Fiqh al-Muamalat;

c. it is advisable to have 5-year (but in no case at least 3 years) experience working in Sharia compliance, Sharia compliance advice, internal or external Sharia audit, internal audit, external audit and assurance, or in other relevant areas;

d. be approved by the SSB with regard to the necessary knowledge and skills according to Sharia principles and rules applicable to IFI and Fiqh alMuamalat." (Official site AAOIFI).

As can be seen from the points presented, knowledge of Fiqh alMuamalat is very important for internal auditors on compliance with Sharia. First of all, such a requirement is justified by the consequences of violation of Fiqh norms, which can be significantly more significant for IFIs than violations of secular legislation. 
In the context of the Islamic financial system, it is expected that the internal auditors of international financial organizations will have not only audit skills as required by professional bodies of internal auditors but also additional qualifications, such as knowledge of Sharia, in particular, Fiqh, to ensure comprehensive compliance with Sharia norms (Ali et al., 2018; Bekkin, 2014).

It is worth noting that in the context of toughening of Russian legislation, increased competition and increased compliance risks, the requirement for specialists to know the legislative and regulatory framework can become one of the factors to increase the efficiency and reduce risks in the activities of not only IFIs but also traditional banks and organizations.

\section{Summary}

From the analysis of the presented standard, it can be seen that in the context of the active spread of Islamic financial instruments, including in non-Islamic countries, stages and procedures for internal audit for compliance with Sharia were developed in detail by AAOIFI and requirements for internal Sharia auditors are clearly described. The methods and procedures of internal auditors for compliance with Sharia are similar to those of ordinary internal auditors, but a significant difference will be in the volume and nature of the audited operations. The emphasis will be on the observance of ethical, moral and social standards, and the effectiveness of the internal audit on compliance with the Sharia will be evaluated on the basis of the ability to ensure confidence in compliance with the Sharia by assessing internal controls, risk management and general Sharia management.

\section{Conclusion}

The presented standard undoubtedly helps to increase the efficiency of using Islamic financial instruments. The Islamic banking system must strictly follow Sharia principles; therefore, full compliance with Sharia rules is the only option for the IFI. An appropriate mechanism will be able to identify and quickly resolve any problems of non-compliance. The proposed standard will provide a reliable basis for internal audit for compliance with Sharia, which will mitigate the 
impact of the risk of non-compliance with Sharia. An internal Sharia audit will protect the interests of Sharia-sensitive partners and increase market confidence in IFIs. Since its field of activity covers much broader aspects of religious, economic and ethical standards, this will ultimately lead to an increase in the effectiveness and social orientation of IFIs, their stable positive reputation and attractiveness, including for partners who are not adherents of Islam.

\section{Acknowledgements}

The work is performed according to the Russian Government Program of Competitive Growth of Kazan Federal University.

\section{References}

Banking according to the canons of Sharia (2018). "Money". Appendix No. 52 dated November 28, p. 13 [Electronic resource]. - Access mode: https://www.kommersant.ru/doc/379868 $\underline{2}$

Official website of Bloomberg news agency [Electronic resource]. - Access mode: https://www.bloomberg.com
Zakaria, N., Ariffin, N. M., \& Abidin, N. H. Z. (2019). Internal Sharia Audit Effectiveness and its Determinants: Case of Islamic Financial Institutions in Malaysia. Kyoto Bulletin of Islamic Area Studies, 12, 8-28

Official site AAOIFI [Electronic resource]. - Access mode: http://aaoifi.com/announcement/aaoifipublishes-exposure-draft-on-internal-

$\underline{\text { Sharia-audit-and-invites-opinion-from- }}$ islamic-finance-industry/?lang=en

Ali, N. A. M., Shahimi, S., \& Shafii, Z. (2018). Knowledge, Skills and Characteristics Requirements for Shari'ah Auditors. Asian Journal of Accounting and Governance, 9, 171185.

Bekkin, R. I. (2014). Features of Sharia supervision in Islamic financial institutions: the modern experience of Muslim and non-Muslim countries. Bulletin of St. Petersburg University, 3. Arwani, A. (2018). Issues and Challenges of Shariah Auditing in Islamic Financial Institution and Corporate Governance Compliance. 
Media Riset Akuntansi, Auditing \&

Informasi, 18(2), 169-186.

Khalid, A. A., Haron, H., Sarea, A. M., \& Masron, T. A. (2018). The Role of Shariah Supervisory Board on Internal Shariah Audit Effectiveness: Evidence From Bahrain. Academy of Accounting and Financial Studies Journal, 22(5), 115.

Kharisova, F. I., Yusupova, A. R., \& Kharisov, I. K. (2018). General characteristics of accounting standards for Islamic financial institutions. International Accounting, 21(3), 138148.

https://doi.org/10.24891/ia.21.2.138

Ryabchenko, L. I. (2018). Prospects for the development of Islamic banking in Russia. University Bulletin, 9, 140-146 